Article

\title{
Ethical Universals in Amitav Ghosh's Sea of Poppies: A Posthumanist Critique of Universal Human Rights
}

\author{
Arnab Dutta Roy \\ Department of Literatures, Cultures \& Languages, University of Connecticut, Storrs, CT 06269, USA; \\ arnab.roy@uconn.edu; Tel.: +1-678-488-7998 \\ Academic Editor: Myra Mendible \\ Received: 1 June 2016; Accepted: 26 July 2016; Published: 29 July 2016
}

\begin{abstract}
The debate on universality in current human rights scholarship has been overly limited. Commonly, the idea is either dismissed as Eurocentric or it is compared to a global political consensus. I evoke certain alternate and underexplored views on the topic from literary and culture studies. Scholars like Kwame Appiah, Patrick Hogan and Seyla Benhabib have articulated principles that include patterns of non-coercive ethical thinking emergent across diverse cultures, particularly the way minority cultures ethically respond to oppression. I argue that human rights practices may be fruitfully guided by the way minority cultures around the world evoke ethical universals to challenge violations. To develop this, I consider Amitav Ghosh's novel Sea of Poppies that treats the issue of colonialism in South Asia during the 19th century. Ghosh foreshadows the arrival of human rights in two ways. He shows that a conception human rights has origins in Western colonialism, precisely in the colonial idea of civilizing mission. But more importantly, he demonstrates that ethical universals allow colonized characters in the novel to form cross-cultural solidarities that subvert colonialism through conceptions of universal human rights. This understanding of universality is largely missing in current human rights scholarship, with consequences that extend well beyond Ghosh's novel.
\end{abstract}

Keywords: universalities; posthumanist; postcolonial; humanism; minoratarian; human rights

\section{Introduction}

Human rights, very broadly, refer to the rights that an individual has simply because he or she is a human being. Human rights, at least as ideals, are universal, and thus, are equally applicable to all humans, irrespective of differences in cultures, races, ethnicities, nations, gender, and so on. However, the topic of universality of human rights is highly contested today, as scholars often disagree on defining the scope and limits of the term, in the context of human rights practices around the world. In this scenario, some mainstream scholars dismiss the idea completely by finding its historical roots in European colonialism. Others treat universality of human rights as a global political consensus, derived from the United Declaration of Human Rights (UDHR). This latter view, however, also follows a historical approach in tracing the origins of human rights doctrines in European continental philosophy, thus, making their views on universality more reflective of a global influence of Western human rights practices on different cultures. In this article, I argue that these mainstream articulations of universality in human rights studies often preclude a more complex interpretation of the idea, especially in considering other relevant issues such as, cultural particularities, minoratarian social justices, and anti-colonial activisms and responses. Thus, I evoke certain alternate and underexplored views on universality, drawn from literary and culture studies. These alternate views treat ethical, and related social principles across cultures in examining key issues of minoratarian identity politics and human rights today.

I begin the article by overviewing two scholarly trends of treating universality in mainstream human rights scholarship. I briefly examine the works of the philosopher Richard Rorty to 
overview the anti-foundational approach to human rights, which dismisses universality as hegemonic. I also look at Jack Donnelly's relative universality, which defines universality as a global political consensus. Finding these approaches limited, I turn next to certain alternate approaches on the topic, in works of literary and culture studies scholars such as Patrick Hogan, Kwame Anthony Appiah, and Seyla Benhabib. These scholars articulate principles that include patterns of non-coercive ethical thinking, emergent across the world in minoritarian social movements against colonialism and other forms of oppressions. I focus on Hogan's social theory of universalism to articulate the difference between universalism and absolutism, and to examine their implication on issues such as cultural xenophobia, representations of indigenous traditions, and minoratarian social movements. I consider Appiah's and Benhabib's readings of cosmopolitanism, focusing on the way they adopt nuanced universal stances on questions of politics and human rights practices. In the final section, I further develop these ideas through a reading of Amitav Ghosh's Sea of Poppies, a postcolonial novel, set against the backdrop of 19th century South Asian colonial history. I consider how the novel evokes certain non-coercive ethical universals to empower minoratarian social justices against discriminatory practices and oppression at both colonial and indigenous fronts. These readings have implications that extend well beyond the scope of fiction.

I situate this study broadly in dialogue with recent developments in posthumanist studies. My reading of alternate universals, however, responds to a specific interpretation of the term "posthumanist". While, in some cases "post-humanist" may refer to all things after "humanism", premised on its outright rejection, my study does not recommend a total dismissal of humanism. Rather, it urges a reinterpretation of the term, in light of certain recent scholarly findings on universality. In the article, I address two distinct universalities, emerging from different accounts of humanism. One, the account that locates universality in the often problematic historical legacy of the Western humanist movement, and thus, in many cases also finds it complicit with European colonialism. This approach is generally presupposed by mainstream scholars in Humanities and Social Sciences, including scholars of human rights. ${ }^{1}$ Two, the approach that finds universality not necessarily as a part of any specific cultural tradition, but rather, in the broad presumption that humans cross-culturally share certain non-coercive emotive states, ethical aspirations, cognitive capacities and experiential impulses ([13], p. 323). ${ }^{2}$ In opting this latter view, this study undertakes a "posthumanist" stance in rejecting certain problematic practices and views historically associated with humanism, while reimagining it in more open-ended and non-coercive terms.

Only recently, have a few literary and culture studies scholars adopted this outlook to discuss how minoratarian social justices share many ethical and experiential motifs in responding to colonialism, and other forms of oppression. I argue that this alternate "posthumanist" reading of universality will allow new ways of critiquing current human rights practices, particularly in reference to key issues of cultural particularities, human rights outreach and activism. Given the nature of this study, one may question the inclusion of literary analysis in the treatment of human rights. In response, I show theoretical findings on non-coercive universals become more plausible through the reading of Ghosh's Sea of Poppies. Though largely fictional, the novel develops how under oppressive conditions,

1 Philosophers like Jacque Derrida [1], Michel Foucault [2], Stanley Fish [3], and Richard Bernstein [4] are well know for their anti-foundationalist views against universality or any trans-cultural moral systems as the basis for reflecting on politics, culture, or human rights. Prominent postcolonial thinkers like Bill Ashcroft [5], Gauri Vishwanathan [6], and Aijaz Ahmed [7] are amongst the many who have treated universality as hegemonic, and thus, a product of Western colonialism. Many social scientists like Evelyn Nakano Glenn [8], Iris Marion Young [9] have also adopted similar approaches in treating issues of citizenship. Other than Rorty [10], scholars like Bernstein [4], Hilary Putnam [11], and Gertrude Himmelfarb [12] have adopted an anti-foundationalist position in examining ideas of universal human rights.

2 Here, proponents have clarified that universality does not suggest that all humans are the same, or think in the same way. The idea simply recommends that there are certain non-coercive structures of thought and behavior that have influence over the way humans around the world interact with each other and establish socio-cultural contact [13]. In addition, see works by Mukti Mangharam [14], Martha Nussbaum [15], Amartya Sen [16], Bandana Purkayastha [17], and Judith Butler [18]. Additionally, see works by Kwame Anthony Appiah [19,20]. 
circumstantial solidarities between minority characters, emerging from vastly different socio-cultural backgrounds, become the basis for anti-colonial resistance and activism. These solidarities, as the novel reveals, are rooted in certain universal conceptions of ethics and social justice consistent with the theoretical universals identified in the larger theoretical study. ${ }^{3}$

Before moving forward, it is worth emphasizing that the views of Rorty and Donnelly do not represent the entire thinking of mainstream human rights scholarship today. On the contrary, they illustrate two predominant ways of thinking about universality and human rights in recent times. Indeed, Rorty is not the only proponent of the anti-foundationalist thought in human rights, there are many others who subscribe to similar ideas in their deliberations of human rights practices around the world. These include figures like Hilary Putnam, Richard Bernstein, among others. ${ }^{4}$ Similarly, Donnelly is also not the sole proponent of the relative universality approach in human rights, there are others like Michael Freeman and Wiktor Osiatynski, who have adopted similar methods in framing universal human rights. ${ }^{5}$ However, the choice of Rorty and Donnelly, in the study, is primarily on account of their exemplary contributions to these areas (even though, a bit dated now), which has to a great extent, allowed other scholars in the field to follow their examples.

On the other side of the spectrum, Hogan, Appiah, and Benhabib are not the only ones to challenge such mainstream perceptions of universality, and human rights. Though still largely underrepresented, scholars are increasingly becoming aware of the limitations of the more traditional canons of human rights scholarship, particularly, the treatment of the idea of universality. To this end, many have challenged West-centric models of human rights, and recommended more culturally inclusive ways of treating such topics. To take an example, $\mathrm{Na}^{\prime}$ im observes that the current framing of human rights fails to accommodate Islam sufficiently, thus, rendering its claim of universality counter-productive and obsolete ([23], p. 58). As Na'im reflects, such limitations can be overcome through discussions about reframing the official language of human right in more open-ended terms. To this end, he feels that this

3 To address the question of universality, one must also briefly consider the debates about the origins of modern human rights practices. Many feel that the consolidation of human rights as practical frameworks traces back to the establishment of League of Nations in 1919, followed by its replacement by the United Nations in 1945, making it centrally a part of a Western legacy. However, on the other hand, many others feel that defining human rights exclusively in terms of this Western legacy is problematic, as it not only precludes a more culturally inclusive understanding of the term (to address the requirements of current times), but also makes it suspiciously a front for neo-colonial Western interests. These debates have further led to disagreements regarding whether or not it is possible to articulate an alternate, and more culturally diverse understanding of human rights practices. As a result, many human rights scholars, in recent times, including Upendra Baxi [21], Makau Matua [22], Abdullahi Ahmed An-Na'im [23], Debora Weismann [24], Mangharam [14], and several others, have insisted on a radical revision of the way human rights practices are approached by current academia. Here, they have felt that the articulation of human rights as a framework should also centrally take into account social justices emerging from under-represented non-western societies, and cultures (that are often overlooked in the present system). One may question the usefulness of approaching these issues through theoretical works that fall outside the canons of mainstream human rights scholarship. In responding to this, I argue that my adoption of a non-traditional theoretical framework allows me to examine the question of universality as it relates to broader issues of culture and politics, with valuable (and until now under-explored) implications on human rights practices. Additionally, it also allows my analysis to overcome certain academic biases that undergird a strictly traditional human rights approach. These include biases relating to the articulation of a strict historical framework of human rights, biases adhering to a particular way of defining the legal and judiciary norms of current human rights practices, and so on. The theoretical findings of Hogan [13], Appiah [19,20], and Benhabib [25] are exemplary in the way they identify (and suggest) a cross-cultural influence of certain ethical and related principle on minoratarian social movements.

4 See, for example, [4,11].

5 Freeman [26,27] and Osiatynski [28] can be very generally grouped as relative universalists, however, their methods are different from each other and from Donnelly [29]. Freeman, at a basic level, acknowledges that modern human rights doctrines began with the philosophical works of John Locke, and universality of contemporary human rights can be broadly articulated through the deliberations of the UDHR. However, his main academic focus has been to reflect on the relative history of modern human rights doctrines, as developed by different foundational and anti-foundational approaches. Moreover, he strongly disagrees with Donnelly regarding the view that "overlapping consensus" on certain human rights should lead to moral obligations for all. Here, he states that a majority consensus may or may not represent the interests and needs of minorities around the world, and thus, should not be the prime basis for reflecting on universality of human rights. Osiatynski, on the other hand, also acknowledges, at a basic level, the Western origins of modern human rights. However, his views on universality are more conceptual than Donnelly, focusing more on notions of human dignity and respect, rather than concrete deliberations of the idea through the UDHR. 
reframing can happen by following two steps (particularly, when it concerns Islam). One, an internal discussion among Muslims, about the reinterpretation of certain aspects of Sharia (the normative system of Islam), especially issues of equality for woman, and freedom of religion ([23], p. 58). Two, a cross-cultural dialog between Muslims and Non-Muslims, about rearticulating the language of international human rights, to be more accommodating to Islam ([23], p. 58). Of course, he also observes that this two-step dialogue is not exclusive to Islam, but can also be extended to initiate conversations between human rights and other socio-cultural and religious systems around the world. $\mathrm{Na}^{\prime} \mathrm{im}$ is not alone in his efforts. Others like Mangharam, Matua, Baxi, and Purkayastha have also adopted strong positions against institutional and Eurocentric models of human rights, and urged more culturally particularistic readings of universal human rights. Even outside the strictly human rights frameworks, few thinkers have endorsed alternate ethical universals in the treatment of cultures and identities. Here, scholars like Judith Butler, Martha Nussbaum, Ashis Nandy, and Amartya Sen are amongst the few who stand out. They have adopted nuanced and original ways of engaging universality with issues such as postcolonial histories, cultures identities, genders, among other things. ${ }^{6}$ However, the choice of Hogan, Appiah, and Benhabib, in this particular study, is topical. While, their individual treatments of the topics demonstrate a range of academic efforts that has led to the revival of the study of universalism in recent years. Their treatment of empathic and ethical forms of universality are particularly noteworthy in the study of literatures like Sea of Poppies, where similar themes and motifs can be identified. Nonetheless, since the broader aim of the article is to formulate an academic model to study alternate universals in human rights, culture, and literary studies, it can be extended to other literatures and theoretical works that evoke similar ideas.

\section{Mainstream Universalities}

Rorty adopts an anti-foundational stance in treating key questions of human rights. ${ }^{7}$ He questions the relevance of any universal moral principle as the basis for articulating human rights. This becomes somewhat clear in his critique of "rationality", a concept that he asserts is the one of the most fundamental units of "shared humanity", and thus, is often coopted as the moral framework of universal human rights ([10], p. 246). Rorty defines "rationality" as an ideological instrument of oppression, that has historically allowed oppressive cultures and societies to create false hierarchies between "true rational humans" and "humans who are not worthy of humanity or who do not possess rationality" [10]. Through this interpretation of "rationality", Rorty critiques the rationales of discrimination in Western colonialism, slavery, and even modern genocides. To take an example, he finds rationality as the basis for human rights violations in the Bosnian genocide against Bosnian Muslims, committed by Bosnian Serbs in the early 1990s. Here, Rorty reveals that the "Serbian murderers and rapists" did not view themselves as violating human rights ([10], p. 242). On the contrary, he states that the crimes were not committed against fellow human beings, but against Muslims, who were "not worthy of humanity" ([10], p. 242). Thus, in critiquing "rationality" as a justification for violence against Serbian Muslims, Rorty observes "they (the Serbs) are not being inhuman, but rather discriminating between true humans and pseudo-humans. They are making the same sort of distinction as the Crusaders made between humans and infidel dogs, and the Black Muslims make between human and blue eyed devils ..." ([10], p. 242). These reflections make clear Rorty's position that rationality has historically served to preserve (and empower) structures of discrimination and oppression leading to human rights violations, both in the West and outside.

\footnotetext{
Also see, for example, [30]. This discussion is taken up in more details later. See [14-18].

The strongest opposition to universality comes from the anti-foundational approach, a branch of modern philosophy that questions the efficacy of knowledge systems that establish a trans-cultural/trans-social basis for defining metaphysical categories such as truth, reality, human nature and capability, and so on. These thinkers recommend that such categories do not have a universal significance, but rather are contingent on factors such specific histories, traditions, and socio-cultural organizations among other things. Prominent studies in anti-foundationalism can be found in the works of scholars including Rorty [10], Fish [3], Foucault [2], Derrida [1], among others.
} 
While, Rorty does not directly treat universality with reference to human rights, his general rejection of foundationalist ideas such as shared humanity amply clarifies his position on universality.

While the anti-foundationalist approach is prominent among many human rights scholars invested in universality and related concepts, it is not the only one. Many mainstream scholars have also articulated universality in terms of the larger (and expanding) judicial frameworks of the UDHR, originally adopted in 1948 by the United Nation. ${ }^{8}$ This approach is best represented by Donnelly. Donnelly has famously endorsed the notion of relative universality of human rights. His views foreground universality of human rights practices primarily through conceptions of "international legal universality" and "overlapping consensus universality" [29]. ${ }^{9}$ Here, "international legal universality" mainly refers to the proclaimed universality of human rights documented in the UDHR. Donnelly states that virtually all states around the world accept the political authority of the UDHR. And in this sense, human rights, in contemporary times, are roughly the rights documented in the Universal Declaration ([29], p. 280). Moreover, he mentions that although "international legal universality" functions at an elitist interstate level, today increasingly the language of human rights adopted from the UDHR, has penetrated to deeper levels of social movements around the world. This point is clearly articulated in his observation: "Movements for social justice and of political opposition have increasingly adopted the language of human rights. Growing numbers of new international issues, ranging from migration, to global trade and finance, to access to pharmaceuticals are being framed as issues of human rights" ([29], pp. 288-89). On the other hand, Donnelly defines "over-lapping consensus universality" as the conception of political universal, accomplished through an overlapping agreement on certain doctrines of political justice. He states that while human rights can be generally based on a variety of doctrines derived from religion, morality or politics, "over-lapping consensus universality" is primarily political, and in this sense, is focused "to further human good or utility, or to establish institutions to provide virtuous citizens" ([29], p. 289). On this note, Donnelley also claims that human rights, as a doctrine, was first developed in the modern West, especially in John Lock's The Second Treatise of Government in 1689. This development, as he finds, assumed a central role in the American and French Revolution that led to the creation of new political orders ([29], p. 288). In this reference, he emphasizes that human rights ideas and practices did not however emerge from any deep "Western cultural root". On the contrary, it was consequential to the specific socio-economic and political transformations of Western modernity ([29], p. 288). ${ }^{10}$

Clearly, both the anti-foundationalist and the relative universality approaches foreground effective critiques of human rights, especially in considering its particular implications on history and socio-political developments. The anti-foundational approach effectively responds to the ideological functions of discrimination in historically oppressive regimes of Western colonialism and other institutional genocides. Donnelly's relative universality, on the other hand, provides a comprehensive account of human rights, and its global applicability through UDHR. However, I contend that their approaches to universality are limited as they develop the idea only in reference to certain elite frameworks of history and practices most notably in the West, leaving out other more cross-cultural

8 The declaration consists of several articles of Universal Human Rights, elaborated through international treaties, laws, regional, national and international instruments, constitutions, among other factors. Also, see [26-28] for other approaches to the topic.

9 It must be noted that Donnelly also provides a preliminary distinction between notion of conceptual universality and substantive practices of human rights. While, conceptual universality primarily refers the ideals of universality of human rights, substantive practices of human rights draw on such ideal conceptions to create legal and political frameworks where claim of human rights can be made, nationally or internationally [29]. Additionally, see Freeman's critique of Donnelly's relative universality $[26,27]$.

10 On the matter of religions, he claims that even though most religions of the world including traditional Christianity, Hinduism, Islam, Confucianism, and African religions have had conceptions of human wellbeing, they have lacked any elaborate system of human rights, that professed equal and inalienable entitlements of rights to individuals, that could be exercised against the state and society ([29], p. 284). He emphasizes that his claims do not suggest that religions, such as Islam and Confucianism, cannot support international human rights. On the contrary, he says that these systems did not in fact develop significant bodies of human rights ideas or practices prior to the twentieth century ([29], p. 286). 
and minoritarian considerations of such ideas. In this sense, Rorty's critique of "shared humanity" is derived exclusively from a reading of an elite rationality that has historically served powerful regimes to discriminate against marginalized populations. ${ }^{11}$ On the other hand, Donnelly's reflection on universality is exclusively immersed in the political tradition of the United Nations, which is often limited to elite levels of international politics. The elitist references in Donnelly is further confirmed through his views on minoratarian social justices, that are singularly informed by the more global and mainstream discourses of UDHR (which he admits to on several occasions). ${ }^{12}$ Ultimately, his admittance about the origins of human rights doctrine as Western, and his elaborations on concepts such as "international legal universality" and "overlapping consensus universality" make it clear that his universality mainly reveals the global outreach of particular Western discourses on human rights. ${ }^{13}$ Thus finding these views inadequate, I turn next to certain theorists who provide alternate and more flexible interpretations of universality, as they relate to human rights.

\section{Alternate Minoratarian Universals}

In Colonialism and Cultural Identity: Crisis of Tradition in the Anglophone, Hogan approaches universality, or what he calls universalism, through the conception of postcoloniality. Postcoloniality, in this sense, may capture a range of different ideas that include personal or collective experiences of colonial persecution and oppression, the socio-cultural histories of colonized or previously colonized individuals or groups, the representations of identities immersed in or emerging out of colonialism, the changing postcolonial realities of politics and culture in the current times, among many other things. Addressing many of these ideas, Hogan reflects that while the myriad experiences of colonialism are contextual as the resultant human suffering is ultimately individual and personal in nature [13]. Nonetheless, "there are some responses that, though partial, are uniformly valuable in opposing colonialism and the human pain it entails" ([13], p. xv). These responses, as Hogan finds, have a basis in universalism. In developing this view, Hogan is particularly aware of the broader academic tradition that defines universality as Eurocentric and also hegemonic on many occasions. To this end, Hogan clarifies that all forms of racism and colonial ethnocentrism are anti-universalist, as they necessarily assume profound and consequential differences between people and cultures. On the contrary, he finds that "universalism involves a self-conscious effort to understand precisely what is common across different cultures-empirically, normatively, and experientially" ([13], p. xvi).

These distinctions further allow him reflect on the nature of coercive ideologies, that are generally mistaken with universalism. For instance, he states that absolutism, with which universalism is generally confused, "is that view that one particular set of cultural views applies to all" ([13], p. xvi). Here, he observes that "it is possible that one might make mistakes, as it is easy to slip into absolutism from universalism. However, in that case, the problem is not with the pursuit of universalism, but rather, with one's failure in the pursuit: it arises when anti-universalist tendencies arise, consciously or unconsciously" ([13], p. xvi). ${ }^{14}$ Furthermore, Hogan finds that human beings broadly adopt

11 Moreover, Rorty's conception of human rights, in general, is developed in response to a broader canon of philosophy originating in the West. While, his analysis and subsequent rejection of rationality is informed by his skepticism towards the greater philosophical tradition of Plato, followed by Kant. His endorsement of a more culturally relative moral framework for human rights emerges from his reading of David Hume's conception of sentimentality [10].

12 While, Donnelly's view that social movements today evoke the language of human rights derived from the UDHR is true on many accounts, however, he largely discounts the fact that social justices around the world are also shaped by the cultural circumstances from where they emerge [29].

13 It must be noted that the problems with these articulations on universality do not arise because these thinkers have chosen specific Western frameworks in reflecting on universality. The problems arise mainly when these frameworks become absolute (and rigid) categories of defining universality, leaving out other possible interpretations of the term. Both in Rorty and Donnelly, universality assumes an absolute nature in the way it finds articulation either in particular histories of oppression, or specific socio-political practices [10,29].

14 Hogan reflects that universalism does not lead to an evacuation or abolition of cultural particularities and histories. In this respect, Hogan states that it does not follow from universalism that all humans are the same, and think in a similar way. On the contrary, he expresses universalism as an effort to reveal cross cultural continuities and the common modes of human thoughts and actions that underlie seemingly diverse practices of cultures and human traditions [13]. Additionally, see [31]. 
universal stances in responding to oppression, colonial or otherwise, and these responses are often expressed in the spheres of empathy and ethics. This allows him to reflect on conceptions of empathic and ethical universalisms. He observes that empathic universalism is informed by an empathic identification with the other's point of view, that is very different from our own ([13], p. 323). The other, in this context, mainly represents marginalized populations and oppressed groups and these identifications are broadly based on feelings, emotions, experiential and ethical aspirations shared by people cross-culturally. Ethical universalism, on the other hand, refers to the development of non-coercive ethical views that challenge colonialism and oppression from the diverse perspectives of minority cultures or oppressed groups. ${ }^{15}$

These reflections by Hogan have a direct relevance to studies in human rights, particularly studies of human rights violations and social justices. By analyzing a broad range of postcolonial literary works by authors including Derek Walcott (West Indies), Rabindranath Tagore (India), Attia Hosain (India), Earl Lovelace (Trinidad), among others, he establishes effective ways of evaluating broader trends of discrimination that often lead to human rights violations against minority cultures around the world. In addition, he finds insightful ways of identifying the larger ethical motifs that empower anticolonial activism and social justices around the world, seen through the particular literary works and individual stances by authors on these issues. Hogan's proposition, thus, points towards a revival of universalism in non-coercive minoratarian terms, with implications on politics and culture. However, he is not alone. Indeed, others like Appiah have held similar views on universality and its influence over social movements around the world. Thus, building on Hogan's views, the next section takes up Appiah in treating this larger revivalist scholarship on universalism, particularly in his reading of cosmopolitanism.

Appiah broadly sees cosmopolitanism as emerging from two interconnected moral views. One, the universal view that we as human beings have obligations to others, "obligations that stretch beyond those to whom we are related by the ties of kith and kind, or even the more formal ties of a shared citizenship" ([19], p. xv). Two, the culturally particular view that we are obligated to take seriously the values of not just of human lives in general, "but of particular human lives, which means taking an interest in the specific practices and beliefs that lend them significance" ([19], p. xv). Here, Appiah adds that cosmopolitanism often poses challenges, rather than providing solutions to issues of politics and ethics in contemporary times. In this respect, he expresses that cosmopolitanism refers to sentiments or attitudes, rather than ideologies. While ideally, cosmopolitanism comes with the awareness that people are different, and mutual respect for those differences should lead to a global system of political interaction. In reality, universal concerns often come to contradict and undermine certain particular claims of "individual's differences." Consequently, Appiah finds that cosmopolitanism, as sentiments, can lead to good or bad results. He reminds his readers that historically, certain forms of cosmopolitanisms have served to propagate rigid views of narrow Christian morality to justify xenophobia and colonialism (among other things); “Christian cosmopolitanism is as old as the merger with the Roman Empire, through which Stoicism came to be a dominant shaping force of Christian ethics ... only someone ignorant of the history of Church will see this as a divided loyalty" ([20], p. 23). On the other hand, he adds that cosmopolitan views have also been foregrounded to advocate against

15 Here, Hogan points out that ethical universalisms have been historically evoked, on many occasions, in anti-universalist ways. In this sense, cross-cultural claims to ethics have often been the basis for discrimination and oppression against minorities within larger historical frames of oppressive regimes and colonial politics ([13], p. 323). However, Hogan reasserts that these tendencies have never really expressed impulses of universalism, rather, they have demonstrated how culturally specific ideologies of absolutism often justify their politics by pretending as universals. Consequently, Hogan feels that non-coercive ethical universalisms are developed through a "Politics of Otherness" that seeks to counter absolutist tendencies "by an imperative that one should focus one's critical scrutiny first and foremost on one's own culture and that, in cases of real conflict-ethical or otherwise-one should give tentative preference to the alien culture, other things being equal" ([13], p. 324). Thus, while fostering a system of ethical principles that have normative relevance over different cultures, non-coercive ethical universalism also functions through a critical system of evaluation that assesses the implications of such ethical norms over the cultures and societies in question [13]. 
histories most violent and oppressive regimes. For instance, he expresses that "both Hitler and Stalin—who agreed about little else, save that murder was the first instrument of politics-launched regular invectives against cosmopolitanism ... and while, for both, anti-cosmopolitanism was a euphemism for anti-Semitism, they were right to see cosmopolitanism as their enemy" ([19], p. xvi).

In treating cosmopolitanism, Appiah recognizes the real dangers of conceptualizing universality or difference in politics. He endorses an attitude towards cosmopolitanism that enables him to simultaneously dissociate cosmopolitanism from radical nationality, and total rootlessness. He observes that proponents should avoid radical nationalism, as that would certainly lead to a politics of discrimination, where certain populations would become privileged over others ([19], p. xvii). Additionally, he states that proponents should also avoid "rootless cosmopolitanism", as that would perpetuate the false ideas that cultural differences and particularities do not matter ([19], p. xvii). In this regard, Appiah states that the idea of "partial cosmopolitanism" can be an effective way of approaching questions of universality and difference in politics. He foregrounds "partial cosmopolitanism" in referring to the idea that even though the loyalty of an individual primarily lies with human kind, that does not mean that an individual should abandon a sense of rootedness with his/her home-land(s) ([20], p. 26). ${ }^{16}$ This idea is clearly found in his following reflection: "We cosmopolitans can be patriots, loving our home-lands (not only the states where we were born but the states where we grew up and where we live). Our loyalty to humankind-so vast, so abstract, a unity-does not deprive us of the capacity to care for people closer by - the notion of a global citizenship can have a real and practical meaning" ([20], p. 26). This approach of partial cosmopolitanism centrally informs Appiah's larger critique of Afrocentric identity politics and writings on black identities. ${ }^{17}$

Appiah's views on cosmopolitanism are consistently evoked through parallels with human rights. For instance, in reflecting on the nature of human rights, he finds that "the idea of the equal dignity and rights of all persons can be cashed out in different ways" ([20], p. 25). However, he asserts they become meaningful only when informed by a "democracy of unlimited franchise; the renunciation of sexism and racism and heterosexism; the respect for the autonomy of individuals which resists the state's desire to fit us to someone else's conception of what is good for us and the notion of human rights" ([20], p. 25) Here, it is suggestive that the moral claims of human rights (like cosmopolitanism) should ideally function to resist all forms of culturally specific absolutisms, that include racisms and sexisms, leading to a more culturally inclusive and minoratarian framework for approaching human rights practices. However, at the same time, his observations subtly allude to a disjunction between human rights as ideal of universality and practices, which on many occasions function to serve larger ends of cultural absolutism. These reflections will allow an effective transition to our next thinker, Benhabib, who conceives the connections between cosmopolitanism and human rights in a more comprehensive manner.

Benhabib presents cosmopolitanism as a model for global politics, that is simultaneously sensitive to particularities of cultures and people and human universalities based on cross-cultural similarities of aspirations, moral beliefs, and so on. In this sense, she distinguishes between two forms of universalisms, elitist universalism and cosmopolitanism. Elitist universalism broadly refers to practices

16 For Appiah, home-land, does not only signify one's nation of birth, it could be any place that an individual finds himself in, through experiences of diaspora, or exile (or any other way), that has fostered a sense of attachment or belonging in him/her [20].

17 We must note here that for Appiah "partial cosmopolitanism" is not so much a system global politics. Rather, "partial cosmopolitanism" represents an attitude towards thinking about politics. For Appiah, the approach of partial cosmopolitan becomes an effective model of engaging politics in two specific ways. First, it allows him to critique existing colonial and neo-imperial structures of oppression and also reflect on the manner in which these structures become oppressive to certain people and cultures (in question). Second, it also enables him to highlight the ways by which such oppressions are challenged through the development of certain motifs and practices of cultures in those societies. In his own works, his model of partial cosmopolitanism has not only allowed him to critique absolutism in conceptions of Eurocentricism and Afro-centrism, as they impact existing marginalized cultures and populations in Africa. His works have also highlighted how such absolutist models of political practices have been challenged through alternate views on African politics and culture (this is particularly clear in his reading of the works of the prominent writer and activist W. E. B. Du-Bois) [20]. 
that conflate dogmatic ideologies of nationalism, or any form of political/social/ethical essentialism as the universal norms for the world ([25], p. 2). For instance, she mentions that a good example of elitist universalism, can be found in those views that take American nationalism and exceptionalism to an extreme, and who want to spread democracy across the world, wholly, on the notion that American is the "most universal nation" ([25], p. 2). On the other hand, she notes that cosmopolitanism demands no such privileged attitude, but rather, it involves a self-conscious union of unresolved contrasts: "between particularistic attachments and universalist aspirations; between the multiplicity of human laws and the ideal of a rational order that would be common to all human cities; and between belief in the unity of humankind and the healthy antagonisms generated by human diversity" ([25], p. 2).

Benhabib takes up the connections between cosmopolitanism and contemporary human rights practices more comprehensively by considering Immanuel Kant's theoretical contribution to conceptions of International justice and human rights. On this account, she evokes Kant's designation of "Third Article of perpetual peace", in elaborating "cosmopolitan rights". She states that Kant designates the Third Article of perpetual peace with the term of "Weltbiirgerrecht", within legal frames of international rights: "Cosmopolitan Right shall be limited to the conditions of universal hospitality" ([25], p. 6). Here she asserts that Kant understood the ambiguities of the term "hospitality", and hence stated that hospitality does not so much refer to the notion of "philanthropy", but of "right" ([25], p. 6). In other words, hospitality is not to be understood as a virtue of sociability, or as the kindness and generosity that one may show to strangers who come to one's land, or who become dependent upon one's act of kindness through circumstances of nature or history. Rather, hospitality is a right which belongs to "all human beings insofar as we view them as potential participants in a world republic" ([25], p. 6). On this account, Benhabib notes that Kant's deliberation of cosmopolitan rights as basic human rights has largely influenced contemporary legal formulations and practices of human rights (for instance, she takes the examples of the Geneva Convention especially on the Status of Refugees of 1951). ${ }^{18}$ It is clear that Benhabib chooses Kant's cosmopolitanism in considering justice systems and human rights practices. These reflections, in turn, become the cornerstone for her own ideas about human rights and cosmopolitanism.

In a theoretical sense, Benhabib acknowledges that cosmopolitanism involves a "recognition that human beings are moral persons equally entitled to legal protection in virtue of rights, that accrue to them not as nationals, or members of an ethnic group, but as human beings as such" ([25], p. 9). However, her endorsement of cosmopolitanism does not emerge through an uncritical view of its role in the larger legacy of Western politics. The theoretical distinction between cosmopolitanism and elitist universalism allows her develop the idea of "cosmopolitanism without illusions." Here, she claims that in the light of recent deliberations of international laws through countless treaties, covenants, and, declarations, cosmopolitanism has been often evoked to serve larger neo-colonial interests ([25], p. 14). She observes that terms like universal human rights, and cosmopolitanism have been used increasingly to justify human rights violations against minorities, seen in cases such as "the illegal war against Iraq carried out by the United States and it allies or the US patriot act of 2001 that gave the President unlimited and quasi-emergency power to conduct the "so called global war on terror," among other events ([25], p. 14). However, she asserts that these cases are examples of elitist universalism, emerging from the perversion of non-coercive cosmopolitan principles. Thus, through "cosmopolitanism without illusions," Benhabib foregrounds an initiative to re-conceptualize, in non-coercive terms, the way legal advances in human rights could foster the growth of "counter hegemonic transnational movements, claiming rights across borders in a series of interlocking democratic iterations, and re-inventions and re-appropriations of valuable norms that have often been misunderstood and abused" ([25], p. 15). Benhabib, Hogan and Appiah, in different ways, acknowledge that universalities can (and do) often

18 This principle obliges signatory states not to forcibly return refugees and asylum seekers to their countries of origin if doing so would pose a clear danger to their lives and freedom ([25], p. 7). 
become proxy to more overt forms of absolutisms. However, they do not find them as reflective of open-ended principles of universalism or shared humanity. Rather, they demonstrate, how such forms of absolutisms are essentially anti-universal, and serve specific socio-cultural ends (colonial, neo-colonial or otherwise). On this account, they also show how open-ended principles of universalism (or cosmopolitanism) can be evoked by minoratarian social activisms and responses against oppression. In the next section, a reading of Ghosh's Sea of Poppies, will allow us to identify broader universal motifs in different minoratarian ethical responses to colonial and indigenous forces of oppression.

\section{Sea of Poppies}

Sea of Poppies explores the history of colonialism from a kaleidoscopic vision of the colonial world, spanning from the early 18 th to the beginnings of the 19th century. Though mainly centered on colonial politics in India, Ghosh's novel connects historical events such as the slave trade in the Americas and the Caribbean, and the opium trade in South East Asia. It traces the fictional journal of a former slave ship, Ibis, travelling from Baltimore, to the southern shores of Mauritius on an assignment to transport prisoners to a colonial prison institution in the islands. The novel develops the personal histories of characters who represent diverse cultural and ethnic backgrounds, such as African American, British, French, Indian, and Chinese. Ghosh presents a strong narrative dialectic in which these characters embody different social roles and attitudes, to highlight a multiplicity of cultural responses to both colonial and indigenous politics of the time. Broadly, I show that these social attitudes allow two ways of approaching cultural representations in the novel. One, representations seen through communal attitudes. Characters exhibiting this attitude treat culture, and hence, social relationships by conforming to rigid and often un-reflexive norms of ethnocentrism. This attitude is generally found in characters who occupy some position of power, either at a colonial or an indigenous level. Here, social identification is strictly limited to considerations of race, economy, class, caste, gender, language, and cultural divisions and hierarchies. While, this attitude evokes static divisions between identity categories such as colonizer and colonized, rational European and barbaric natives, master and slave, colonial masculinity and indigenous effeminacy (and impotency), it is also manifest at the level of indigenous politics. Within these spheres, social-cultural engagements are controlled through a dogmatic traditionalism, seen in practices and ritualistic iterations of purity along lines of religion, caste, class, gender, custom, and scriptural validations [32]. ${ }^{19}$ Two, representations seen through empathic attitudes to cultures. Character exhibiting this attitude often find empathy as the basis for cross-cultural/social interactions. This attitude is generally found in characters that occupy minority or marginalized positions. Empathic associations between characters emerging through intersections of different races, classes, castes, gender identities, religions ultimately lead to more open-ended and flexible reflections on cultures, traditions and identities. Here, it is noteworthy to clarify that empathic attitudes are not indicative of a total rejection of culture or tradition. Neither, do they recommend that cultures and traditions should be the same or homogenously organized. On the contrary, these attitudes are subversive of certain dogmas, rooted in cultures and traditions that inflict socio-cultural practices around the world and allow discrimination. Consequently, these outlooks foster a sensitivity towards socio-cultural differences by finding them in more flexible and non-coercive terms.

The development of these social attitudes are subtly informed by larger positions on universality. The communal attitude effectively represents a projected "worldview" where identities are validated through rigid cultural norms of colonialism or dogmatic traditionalism (that are often assumed to have universal significance). The empathic attitude, on the other hand, serves to uncover and expose the duplicity of the communal models through alternate practices of liberal traditionalisms and cultural universalities. Here, it is worth noting that these discussions are directly related to the question of social justices, thus making them relevant to studies in human rights. From a colonial viewpoint, the notion

19 Ghosh mainly focuses on perceptions of Hindu traditionalism in India [32]. 
of social justice often becomes a justificatory process to preserve coercive norms of colonial politics. This is clearly evident on many occasions when colonial characters from the novel evoke the rhetoric of social justice rooted in logic of the European civilizing mission to justify colonial investments in the opium trade in China, or the Slave trade. Moreover, certain rationales of social well-being are also embedded in dogmatic practices of indigenous traditionalisms developed in the novel, where "cultural purity" becomes a token for collective social good. ${ }^{20}$ On the other hand, such coercive projections get subverted through alternate non-coercive social justices, seen through the different experiential accounts of marginalized characters resisting oppressive structures of colonialism and indigenous politics, both at an individual and collective levels. As I will demonstrate later, these alternate accounts will lead to more open-ended reflections on universality, as it related to human rights.

As established before, the communal attitude is perpetuated through characters who occupy some position of power or authority, either in the colonial or indigenous political context. These characters often unquestioningly organize their social behaviors (and mannerisms) around certain mainstream dogmas associated with their particular socio-political position, their class, their cultural heritage, their caste, among other categories. Within the colonial framework, the socio-cultural interactions of characters exhibiting such attitudes are shaped by larger culture dogmas associated with colonial politics, particularly, politics functioning through prescribed differences between identity categories of colonized and colonizer, British and native, white and black, Christian and non-Christian, among other things. A clear example of this can be found in the character of Benjamin Burnham, an established British businessman representing the East India Company in Bengal, India. Burnham is the owner of a colonial shipping firm responsible for transporting convicts to one of the largest prison systems of the British Raj in the islands of Mauritius. His shipping firm is also invested in the trade of opium, connecting India with China and other parts of the world. Burnham's attitude towards institution like colonialism and slavery is uniquely conditioned through his moral convictions about freedom, rooted in certain dogmatic views about Christianity. For instance, in a conversation with Reid, a junior officer, about freedom, he explains "freedom...is what the mastery of the white man means for lesser races" ([32], p. 70). Taking the example of African slavery, he further explicates "African slavery was the greatest exercise of freedom since god led the children of Israel out of Egypt. Consider ... the situation of the so called slave in the Carolinas-is he not more free than his brethren, groaning under the rule of some dark tyrant?" ([32], p. 70). On being asked about his views on abolition of slavery, Burnham reflects that "when god closes one door he opens another ... When the doors of freedom were closed to the Africans, the lord opened them to a tribe that was yet more needful of it-the Asiatick" ([32], p. 71).

It is clear that Burnham's observations are problematic, as they assume consequential and discriminatory differences between races through different justificatory strategies. Here, the "white" man assumes the role of a biblical savoir and colonialism becomes the institution that allows the possibility for "freedom" for lesser races. On the other end, Africans and Chinese are shown as victims who need to be salvaged from their own savage cultures (and people) through colonialism, much like the way the Israelites were saved by god in the biblical context in his reference. Here, we must

20 Some specific forms of social justice are historically linked to practices of dogmatic Hindu traditionalism, taken up in the novel. For instance, practices such as Sati (widow burning) and untouchability of caste treated in the novel, were in fact historically defended by many narrow Hindu nationalists during the 19th century (in Bengal and Bihar) as necessary to the survival of the 'Hindu tradition,' particularly facing the threat of colonialism. While, the impact of colonialism is not directly felt in the stories of the residents of Ghazipur, a village in Bihar, developed in the novel. The fact that the main source of income in the village is the production of opium (through poppy) is indicative of the larger colonial influence. Moreover, the fact that Ghazipur is located in Bihar, and the time period is 19th century, further complicates the question of "tradition" and social activism in the novel. Thinkers like Lata Mani [33] and Gayatri Spivak [34] have identified that reactions to colonialism led to several reformist movements (of Hinduism) particularly in Bengal and Bihar during the 19 th century. On this account, some secular responses condoned practices such as Sati, and untouchability in imagining a reformed Hindu tradition. Others, coming from a more conservative position, defended these practices as necessary to the survival of tradition. 
note that Burnham does not deny that colonialism causes suffering, however, he justifies the suffering as progress towards freedom: "the march to the shining city is never without pain, is it? Didn't the Israelites suffer in the desert?" ([32], p. 71). These views are not just indicative of Burnham's personal opinion on matters of religion and politics, they also speak to a larger colonial rationale that organizes social behaviors of individuals participating in its politics, along discriminatory viewpoints, behaviors and mannerisms. Hence, it is not just a matter of Burnham expressing his opinions, it is equally important for him to preach these views, and demand a conformity from those he considers his peers, and equals. When Reid expresses his discomfort regarding this perception of freedom: "well if slavery is freedom then I am glad I don't have to make a meal out if it," Burnham retaliates with a rebuke "I thought you were a pucka kind of chap, Mr. Reid" ([32], p. 71). This remark by Burnham, in a way, counts as a warning for Reid to adjust his attitude along certain colonial norms of social acceptability. The term pucka ("hardened" in colloquial Hindi) in this sense, serves as a signifier of an acceptable social status within the colonial framework. It is also suggestive that the title of pucka is not naturally endowed on individuals who seemingly conform to broader identity categories of white and Christian. ${ }^{21}$ On the contrary, the status has to be earned through a ritualistic conformity with the recognized socio-cultural and religious norms of colonialism.

Burnham is not alone in demonstrating this communal attitude. Indeed, there are many other characters conforming to similar trends, in other social spheres of communication and mannerisms. Another suitable example is the character of Mr. Doughty, the captain of the ship Ibis, owned by Burnham's firm. In the novel, Doughty makes it his personal mission to educate Reid, the second officer in the ship, who is newly arrived in India, on mannerisms and etiquettes appropriate to individuals of their social status. During the first encounter between the two in the ship, Doughty finds Reid in a state of undress: "disheveled clothes and bare foot" ([32], p. 21). This provokes a reaction of disapproval in Doughty: "you certainly have let yourself go ... wont do when you are the only sahib on board ... not if you want to be borak-poked by your darkies" ([32], p. 21). Here, it is suggestive that on account of Reid's social position as the only white officer ("sahib"-Hindi for master) in the ship, he must act appropriately to maintain his authoritative presence over the other non-white slaves and workers on board. Otherwise, they will not take him seriously. Thus, in a way, Doughty foregrounds the importance of certain social rituals (like dressing appropriately) that a civilized white man must perform to not only avoid mixing with other lesser races that he comes in contact with, but also to exercise an authoritative influence, that would ensure professional success. On another similar occasion, Doughty advises Reid on the proper use of native language in a colonial context. He emphasizes that it is important for a "sahib" to know a little bit of the indigenous tongue in India in order to maintain a position of authority over the natives: "he would have to learn to gubbrow (intimidate) the natives with a word or two of the zubben (native tongue)" ([32], p. 43). ${ }^{22}$ However, at the same time, Doughty warns Reid against being too well versed in the lingo, as that would negatively imply that he has been claimed by native cultures: "Its easy enough to jin if you put your head to it. Just a little peppering of nigger talk ... but mind your Ordoo and Hindi doesn't sound too good: don't want the world to think you have gone native" ([32], p. 43).

21 On meeting Reid, Burnham assumes that he is white (and probably Christian) on account of Reid's light skin tone, and the fact that he holds the position of an officer in a ship owned by his firm. This assumption is partly wrong, as the novel establishes that Reid is African American with light skin color. His religion, or his views about religion are never really clarified in the novel [32].

22 We must note, the "zubben", which in Urdu means tongue, but colloquially signifies native language, does not indicate any one particular language, spoken traditionally in India (at least, in this particular context). On the contrary, it refers to a language shaped uniquely through the colonial encounter, mainly in colonial metropolitan centers in the the East. It incorporates diverse influences of many languages spoken in the India, as well as other parts of South Asia. These include Bengali, Urdu, Hindi, Chinese, among other languages ([32], p. 93). The zubben, largely makes possible communication between individuals from different cultural and linguistic backgrounds. In the novel, when Reid inquires about the zubben, Doughy explains that the zubben is the "flash lingo of the East" ([32], p. 43). 
These examples mainly reveal how communal attitudes are based in certain narrow and absolutist conceptions of culture and tradition. Moreover, these projections are grounded on the broad assumption that cultures are un-equal, and thus, the following socio-cultural interactions are necessarily consequential to those differences. However, communal attitudes are not only limited to the spheres of colonial politics, they also regulate perceptions of indigenous cultures and traditions. In the novel, communal attitudes are reflected particularly in the way indigenous Hindu communities in India are fragmented through rigid divisions such as caste, class, and social patriarchy. For instances, the novel centrally develops the impact of communal attitudes on the lives of characters located in Ghazipur, a small Hindu village bordering between Eastern Uttar Pradesh and Bihar. Ghazipur is a small farming community next to the Ganges, where the main livelihood comes from the production of poppy, that later, gets processed as opium for colonial export: "the village in which Deeti lived was on the outskirts of...Ghazipur, some fifty miles east of Benares. Like all her neighbors, Deeti was preoccupied with the lateness of her poppy crop" ([32], p. 1). The novel follows the story of Deeti, and her husband Hukum Singh, who in a way, represent a majority of the working class in the village, invested in farming poppy. While, it is suggestive from the family-name "Singh," that they belong to the upper Hindu caste of Kshatriya, it is also evident that they come from a lower economy class; "she (Deeti) had no grain or fruit to spare, and as for money, there was not a dam's worth of cowrie-shells in the house" ([32], p. 23). ${ }^{23}$ Other than this working class, the village also comprises of an elite class of rich Zamindars (landowners): "one of Ghazipur's most prominent landowning families had three young scions, Thakur-sahibs, who were much addicted to gambling" ([32], p. 48). ${ }^{24}$ The village is also home to a small community of the untouchables, members of the Chamar caste (leather workers), who dwell in the periphery of the village: "Kalua lived in the Chamar-basti, a cluster of huts inhabited only by people of his caste" ([32], p. 47).

These social divisions significantly inform the social behavior of the residents of Ghazipur. For instance, the "purist" Hindu view that a direct contact of a higher caste individual with an untouchable would result to the loss of caste is evident in the way Hukum Singh interacts with Kalua, his carriage driver, who belongs to the Chamar caste: "He was of the leather worker's caste and Hukum Singh, a high caste Rajput, believed that the sight of his face would bode ill for the day ahead" ([32], p. 2) ${ }^{25}$ Moreover, these communal attitudes are implicit in the way the Thakurs from the elite Zamindar class (Hindi for landowner) treat Kalua, as a disposable object (lacking qualities of humanness). When Kalua loses a wrestling match for the Thakurs at a local competition, he is humiliated by them: "This animal should be mated with a horse, not a woman" ([32], p. 49). This verbal humiliation later turns into an assault, when the Thakurs forcefully try to make Kalua sexually perform with a horse: "The men forced Kalua to his feet ... stumbling towards the mare's swishing tail ... Kalua uttered a cry that was almost indistinguishable in tone from the whinnying of the horse. This amused the landlords ... See, the b'henchod even sounds like a horse" ([32], p. 50). These instances of communal behavior constitute a dominant mode of social interaction, both in the colonial and indigenous settings. Kalua's humiliation and abuse is not just indicative of individual acts of violation by Hukum Singh or the Thakurs, much like the social outlooks of Burnham and Doughty, are not isolated accounts of the colonial view. Instead, they are organized around worldviews that presume that some cultures (and populations) are superior to others, and thus matter more. The novel, however, provides alternatives to this dominant social perception through the development of more open-ended and empathic perceptions of cultures and traditions, from minority characters

23 The Kshatriya caste, traditionally represents the "warrior caste" in the broader Varna system in Hinduism. Though not clearly established, it is suggestive, in the novel, that the majority of the farming community in the village, like Deeti's family, belong to a lower income Kshatriya caste (except for the ruling class and a small minority of lower caste laborers) [32].

24 Thakur is a traditional title that represents higher Kshatriya class. In Sanskrit, it means godhead, signifying it importance in broader Hindu communities [32].

25 Rajput is also a designation for the Kshatriya caste [32] 
in the novel. Ultimately, these empathic outlooks create possibilities of social resistance and activism against oppression.

Empathic attitudes are generally found in characters who have experienced marginalization on prior occasions within mainstream social contexts. Such characters' usually reject communal attitudes in seeking alternatives to mainstream perceptions of social identification. While, these empathic impulses allow characters to adopt more open-ended outlooks towards culture and society, they also make possible cross-cultural and social bonds of friendship and solidarity (despite differences in race, cultures, genders, social status, and so on). These friendships, however, are a result of common experiences of persecution and marginalization (unique to the particular experiences of the participating characters) ${ }^{26}$ Here, we must draw attention to the fact that categories, such as, minority, and marginalized are broadly defined in this study. They are not necessarily based on static divisions between identity categories of white or non-white, colonial or indigenous, and so on. Minority, comprises of underrepresented groups, or individuals, who on account of factors like number of members or particular social attitudes (in turn based on factors like race, genders, culture, behaviors, beliefs, interests among other things) do not (or are unable to) conform to the dominant norms of a social organization. Thus, minorities are more vulnerable to marginalization than participants who possess the ability and willingness to conform to dominant norms. Marginalization of minorities is largely contingent on (and thus also contextual to) different social circumstances developed in the novel. While, in most cases characters' experience marginalization on account of colonial or indigenous xenophobia based on factors such as race, gender, socio-cultural status, however, in some cases, characters who seemingly conform to social categories of race or class, still occupy minority positions due to their non-conformity to dominant social attitudes, and thus become victims of oppression.

A good example of this can be found in Pierre Lambert and his daughter Paulette, who are French immigrants in Calcutta. Pierre is a botanist in Calcutta's Botanical Gardens. Right at the beginning, we are introduced to the fact that his unusual views on society and religion make him an outcaste both in the larger colonial community of the British in Calcutta and his own country, France: "Pierre Lambert had left his country ... he had been involved in a revolt against his king; that he was shunned by respectable English society because he had publicly denied the existence of God and the sanctity of marriage" ([32], p. 60). These experiences of alienation from mainstream European cultures is perhaps one of the reasons that allow Pierre to form cross-cultural friendships, in non-coercive terms. This is clear in his empathic solidarity with a low class Bengali Muslim woman from Calcutta, who eventually becomes a surrogate mother to Paulette (after the death of Paulette's biological mother through childbirth): "he was greatly relieved when Jodu's mother quietened the baby by putting her to her breast" ([32], p. 59). ${ }^{27}$ Moreover, Pierre's cosmopolitan understanding of different cultures and languages, is directly reflected in Paulette's education and upbringing: "Paulette's schooling had consisted of assisting her father as he went about his work. This provided a wide are of instructions ... in Bengali and Sanskrit...Paulette had learned a good deal of Latin from her father, while also absorbing Indian languages" ([32], p. 118).

These early experiences play a big role in shaping Paulette's social attitude along empathic lines. However, like her father, she becomes an outcaste in the larger colonial community of Europeans in Calcutta, and her behavior (her indifference to recognized communal norms) makes her a source of ridicule and insults. On one such occasion, for instance, she is insulted by Mr. Kendalbushe, a local

26 We must note here that empathic interactions are significantly different from views organized through communal conformity, and thus, must not be confused. While, empathy inspires a non-coercive interaction between participants, who experience a one-ness with each other, on the basis of shared experiences and aspirations, communal conformity, is often obtained through conscious or un-conscious coercion [13].

27 The novel clarifies that she comes from a lower class Muslim fishing community. She is referred to as Jodu's mother, because Jodu is her son, and it is usual for women in many lower class Indian communities to be addressed through their children or husbands (and not by their names) [32]. 
British judge, for her disregard of communal religious views: "Miss Lambert, your godlessness is a disgrace to the ruling class, there is many a Gentoo and Mom 'den in this city who is better informed than yourself" ([32], p. 118). On a different note, however, Paulette's personality (and her upbringing) allows her to identify naturally with customs and traditions in Bengal: "As for Paulette, the first language she learned was Bengali, and the first solid food she ate was a rice and dal khitchri ... In matter of clothing, she far preferred saris to pinafores ... for shoes, she had no patience at all, choosing, rather, to roam the Gardens in bare-feet" ([32], p. 59). Furthermore, these attitudes make her receptive to empathic bonds of friendship at a cross-cultural level. For instance, when she meets Jodu, son of her surrogate mother, and finds out about her recent passing, she embraces him without any considerations of social differences (even to Jodu's surprise): "He had half-expected that she wouldn't understand ... Suddenly alarmed, she pulled his nearly naked body still closer, trying to warm him with her arms" ([32], p. 133). On being discovered in this state of embrace by the second mate Reid, she explains to him "He is like my brother, it was as a sister that I was holding him, for he has suffered a great loss" ([32], p. 135).

Another example of the empathic attitude can be found in Zachary Reid, the second officer of the ship, Ibis. Reid is a mulatto African American sailor from Baltimore, who is the son of a former slave in Maryland ([32], p. 8). Though not clearly established, it is suggestive from the novel the Reid's mother was a slave in a Baltimore plantation owned by his biological father, a white American slave owner ([32], p. 43). Reid's success within communities of white colonial officers is largely a result of his unique ability to impersonate the appearance of a white colonial officer, on account of his polished mannerisms and the lightness of his skin color. We find out early on that his skin color is old-ivory ([32], p. 7). We also know that his mother made sure that as a child, he was trained in mannerisms and etiquettes appropriate in elite White circles "It was true that when called upon, his tongue could be as clipped as that of any college-taught lawyer: not for nothing had his mother made him wait at table when the master of the house, his natural father, was entertaining guests" ([32], p. 45). Reid's social attitude is uniquely shaped through his past experiences of slavery. On one occasion, he recalls his last day in Baltimore before boarding Ibis "He saw a face with a burst eyeball, the scalp torn open where a handspike had landed, the dark skin slick with blood. He remembered, as if it were happening again, the encirclement of Freddy Douglass, set upon by four white carpenters; he remembered the howls, 'kill him, kill the damned nigger, knock his brains

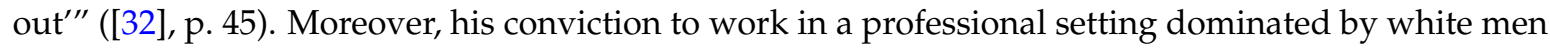
arises out of his fear that black men could never be socially accepted by white people "Its about jobs, the whites wont work with you, freeman or slave" ([32], p. 45). These factors uniquely condition him to associate more freely with the culturally diverse lower class workers and crew members of the ship, rather than elite white officers (though, he is well adjusted in interacting with the latter, as we saw in our discussions on Burnham and Doughty). His unique position of authority in the ship, and his disregard for communal views, inspire the workers in the ships to trust Reid, and naturally bond with him on equal terms. This becomes clearly evident on the occasion when, Serang Ali, a lower class Asian worker in the ship, expresses his solidarity with Reid's social ambition and his dream of becoming the captain of Ibis one day: "Malum must be a proper pukka sahib ... All lascar wanchi Malum be captin bugger by and by" ([32], p. 45). It is this moment that makes Reid really aware of his own unique social situation and of the empathic connection between him and the workers "he was to become what no lascar could be-a 'Free Mariner', the kind of sahib officer they called a malum. For Serang Ali and his men Zachary was almost one of themselves, while yet being endowed with the power to undertake an impersonation that was unthinkable for any of them" ([32], p. 45). ${ }^{28}$

28 This example is also clearly indicative of a "politics of otherness," indicated by Hogan [13] earlier. Here, the workers see Reid as an equal, however they also recognize his unique social advantage within colonial circles (which none of the other workers possess). This allows them to see Reid as a potential leader who would ultimately represent their interests in mainstream social spheres. This issue is taken up further in the discussions on non-coercive social justices later on [32]. 
Empathic attitudes are also manifest in several characters who are immersed in more local levels of indigenous politics and tradition. Empathy becomes the basis for the friendship between Deeti and Kalua, despite the stark social differences between their class and caste. However, this unique bond is conditioned by the fact that they are both victim of mainstream communal practices in Ghazipur. While, Kalua is discriminated on account of his low caste/class status in the community (already shown in previous discussions), Deeti is a victim of coercive patriarchal attitudes, rooted in dogmatic views of Hindu traditionalism. From Deeti's story, we find out that she is drugged and raped on her wedding night by her brother in law, Chandan Singh: " ... that confirmed Deeti's belief that the child in her belly had been fathered not by her husband, but by Chandan Singh, her leering, clack jawed brother-in-law" ([32], p. 34). Moreover, after the untimely death of Hukum Singh, she is pressured by her in-laws to perform "Sati" (widow burning ceremony): "Half dragged and half carried, she was brought to the pyre and made to sit cross-legged on it, beside her husband's corpse" ([32], p. 160). ${ }^{29}$ Kalua's desperate intervention finally allows Deeti to escape her situation: "Kalua placed the platform against the fire, scrambled to the top, and snatched Deeti from the flames ... " ([32], p. 161). It is this intervention by Kalua that dissolves all social differences between the two, and shapes their empathic relationship. This empathic connection is confirmed when Kalua acknowledges to Deeti about their unique situation: "It was myself I saved today, he said in a whisper. Because if you had died, I couldn't have lived" ([32], p. 162). Deeti's final disregard for communal differences, and her commitment to Kalua becomes clear in her suggestion that they should escape somewhere far off and get married "we will find a place where no one will know anything about us except that we are married" ([32], p. 163).

Clearly, both communal and empathic responses to oppression in the novel can lead to pertinent observations on universalities. Hogan, Appiah, and Benhabib, have unanimously felt that all forms of absolutisms are anti-universal, and essentially impose specific cultural outlooks as universal norms for all, leading to the discrimination, and marginalization of many. Communal attitudes emerging from colonial and indigenous situations in the novel are distinctly rooted in such specific ideologies of absolutisms; one being in the service of specific groups benefitting from colonial politics, and the other, in the interest of certain sections of higher class/caste Hindus. Moreover, both the claims are based on certain absolutist conceptions of universality. The colonial view is premised on the presumption that white European races (and cultures) are superior to other colonized cultures around the world, and colonialism, is a unique outcome of this global inequality (suggestive in Burnham and Doughty). Certain claims of universality are also seeded in the asserted superiority of higher caste/class individuals within dogmatic Hindu communities. The novel reveals how these indigenous social standards of purity are not only limited to Hindu communities, but also apply to social interactions between Hindus and non-Hindus, where the former is presumed as superior. For instance, when Doughty and Reid are invited to dinner by a rich Hindu landlord from Calcutta, Raja Haldar, who belongs to the higher Kshatriya caste, Doughty informs Reid about the socially accepted codes of interactions between the two parties: "Keep your hands to yourself ... Touch him and he will be off to bathe, and we won't be fed till midnight" ([32], p. 97). This example consolidates the indigenous communal standpoint that non-Hindu like Doughty and Reid, are socially inferior to higher caste Hindus like Haldar, and any physical contact between them might lead to a contamination of the essential Hindu culture. It is also suggestive, that Europeans, like Doughty, must acknowledge

29 Sati refers to a social practice within some Hindu communities, where a recently widowed wife, either willingly or by force, commits suicide by burning in the funeral pyre of her dead husband. Scholars including Mani and Spivak have treated the history of this practice in Bengal and Bihar, during the 19th century [33,34]. 
this social code, particularly while interacting with characters who hold important social positions within the indigenous social framework. ${ }^{30}$

Despite such projected universal standards, it becomes clear that these communal views are not reflective of open-ended principles of universalism or shared humanity. In fact, the empathic social interactions developed in the novel, provide good alternates on this account, and presuppose more open-ended ethical universalities. Clearly, Hogan's ethical universalities, and the open-ended cosmopolitanisms identified by Appiah and Benhabib, are expressed in behaviors of characters such as Reid, the Lamberts, Deeti and Kalua. All these characters occupy minority positions, in their respective social settings, and consequently, experience varying degrees of marginalization. In a way, their personal experiences increase their sensitivity towards others who may belong to very different socio-cultural backgrounds, but face similar situations of oppression. Thus, facing the cultural confrontations brought forth by colonialism (and other social practices), these characters choose to form cross-cultural alliances based on empathy, rather than conforming to discriminatory social orders. Here again, we must be reminded that these empathic outlooks do not indicate an evacuation of cultures or traditions. Rather, they are subversive of certain discriminatory practices of cultures and traditions, around the world. Consequently, they allow reflections of cultures and traditions in more open-ended terms. Pierre, for instance, does not reject all aspects of European culture. His love for European languages and philosophy is a clear indication. In Paulette recollection of her father, this becomes clear "French she studied, reading and re-reading her father's books ... Paulette had become an accomplished botanist and a devout reader of Voltaire, Rousseau ... " ([32], p. 118). His behaviors and actions are simultaneously indicative of a rejection of communal standards of colonialism, and a more non-coercive understanding of European cultures. Similarly, Deeti's social behavior (particularly her decision to marry Kalua) does not indicate her rejection of the entire Hindu tradition, but rather certain discriminatory dogmas associated with it. Indeed, on many occasions in the novel we find out that Deeti is deeply religious and traditional. A good example is the description of Deeti's personal shrine that simultaneous incorporates figures of Hindu gods and goddesses and other tokens that have symbolic value in her life: "There was a small altar inside, with statues of Shivji and Bhagwan Ganesh, and framed prints of Ma Durga and Shri Krishna ... But the room was a shrine not just to the gods but also to Deeti's personal pantheon, and it contains many tokens of her family and forbears" ([32], p. 6). The inclusion in the shrine, of the ship Ibis, and its cosmopolitan travelers, who later becomes companions of Deeti and Kalua, is indeed an evidence of an alternate

30 The novel makes it clear early on that in Doughty's colonial view, Haldar hold an inferior position owning to the fact that he belongs to a non-white colonized race: "See, if there is one thing I can't abide, it's a bookish native ... wait till you hear the barnshoot bucking in English" ([32], p. 42). However, Doughty's basic acknowledgement of codes of Hindu conduct in this situation is reflective of a social understanding between two elite classes that mutually benefit from each other in the colonial situation. While, Halder's social position as a rich landlord from Calcutta, makes him a consistent source of colonial revenue for Burnham's firm. On the other hand, the colonial support provided to the Haldar family, allows them to more comprehensively consolidate their privileged social positions, within indigenous contexts. Indeed, such beneficial alliances between the British and indigenous elite classes in India were common during later 19th century and early 20th century in places like Bengal and Bihar, where feudalism flourished [35]. 
liberal traditionalism in Deeti, that is open to other socio-cultural influences: "not just the ship, but also many of those who are in it; they too must be on the walls of our puja room" ([32], p. 7). ${ }^{31}$

These non-coercive ethical universals are not merely conceptual in the novel, they lead to clear accounts of minoratarian social justices and activism. In the case of the Lamberts, certain impulses of social activism inform their conscious rejection of mainstream colonial codes, and their adoption of empathic views of culture. Similarly, the outlook of Reid also reveals certain expressions of social justices, subversive of colonial discrimination. His professional success in colonial settings is largely a result of his conviction (as an African American) to subvert communal practices that barred black individuals from being accepted within white professional circles. Moreover, his true alliance lies with the largely marginalized workers in the ship, who recognize his ability to represent their cause in mainstream social spheres. Even in indigenous spheres, empathic solidarities account to instances of social activism against prevalent dogmas of conservative Hindu traditionalism. Deeti's decision to marry Kalua is clearly subversive of mainstream dogmatic Hindu codes that forbid inter-caste relationships, especially between members of higher and untouchable castes. Moreover, Kalua intervention in Deeti's ceremony of Sati is also a clear sign of social rebellion against oppressive Hindu practices.

\section{Conclusions}

The account of social justices in the novel, though largely fictional, can point to broader issues of real life human rights violation, and minoratarian social resistance. By developing alternate universals in Hogan, Appiah, and Benhabib, and relating them to the reading of colonialism and social activisms in Sea of Poppies, the study provides a method of identifying patterns of ethical universalities in minoratarian social movements, at a cross-cultural level. And consequently, these empathic universals can allow new and valuable insights to conceptions of universal human rights. By now, it is clear that mainstream approaches to universality in human rights today are limited, as they fail to take into account such minoratarian conceptions of universality. Rorty's critique of "rationality" is valid only as it identifies certain coercive practices of absolutism, rooted in the West and elsewhere. ${ }^{32}$ However, his conviction that notions of shared humanity and universalism can only express absolutism is limited, and ultimately, counter-productive to broader studies on the nature of minoratarian social movements. Similarly, Donnelly's conflation of the UDHR culture with the idea that human rights practices are Western, is also problematic as it limits universality as a global influence of certain cultural practices, that are presumed to be Western. ${ }^{33}$ Indeed, Benhabib, Appiah and Hogan, provide more flexible accounts of universality, as concerning human rights. In discussing human rights practices, they have felt that universalism as ethical principles cannot be restricted to any one specific culture or society.

31 We must note that Hogan [13], Appiah [19,20], and Benhabib [25] acknowledge (in different ways) that ethical views can ambiguously lead to good or bad results. Hogan admits that historically ethical views have been mobilized to discriminate and marginalize populations. Similarly, Appiah has stated that, cosmopolitanism as attitudes can be good or bad, and historically, certain forms of cosmopolitanisms have expressed racism and cultural xenophobia. Benhabib, on this account, has expressed the open-ended principles of cosmopolitanism are often perverted, leading the rise of elitist universalism. In Sea of Poppies, these trends can indeed be observed. Dogmatic cosmopolitanisms and ethical views are frequently evoked to justify colonialism and dogmatic Hindu outlooks. Moreover, open-ended notions of freedom and justice are also perverted to serve specific colonial goals and interests. At the same time however, these scholars (Hogan particularly) have also felt that non-coercive ethical universals counter absolutisms by fostering a critical awareness about the implications of such ethical claims on different cultures and social identities in question. The Lamberts, for instance, are critically aware about their specific attitudes, within the larger colonial framework. Their conscious rejection of colonial attitude is a sign of social rebellion against mainstream coercive colonial practices. Reid is equally aware of his past. His perception about the colonized workers in the ship, and the colonial officers, are significantly informed through that awareness. Both Deeti and Kalua enter into their circumstantial empathic relationship with the awareness that they belong to two very different caste groups, and their relationship would signify a rebellion against mainstream traditional Hindu perceptions [32].

32 This critique can also be applied to works to other anti-foundational works on Human Rights. For other anti-foundationalist works, see $[9-12,18]$.

33 Additionally, see, for example, $[27,28]$. 
Instead, they have shown that universalism is expressive of certain open-ended ethical values, which different cultural practices (of human rights) around the world can adopt and implement.

It is worth mentioning again that this minoratarian approach to universality is in no way a dismissal of mainstream studies on human rights and culture. Indeed, Rorty and other prominent anti-foundationalists have launched powerful critiques of how absolutisms, in their various manifestations, become oppressive to minoratarian traditions around the world, and seemingly neutral ideas such as universality, pragmatism, rationality, and cosmopolitanism, become proxy to such practices. ${ }^{34}$ Their ideas, on this account, have significantly shaped the way contemporary scholarships in Humanities and Social Sciences have become attentive to existing problems of cultural hegemony, and also, to the resultant socio-cultural and economic inequalities around the world. Furthermore, the contributions of relative universalist, such as Donnelly, Freeman, Osiatyński, among others, are also exemplary, in the way they have articulated certain predominant historical and philosophical frameworks of human rights, as we know them today, and developed strategies of examining socio-political conditions that make human rights implementable. However, despite such worthy contributions, they have been inadequate in conceiving notions of universality in a more comprehensive manner, especially, the way cross-cultural ethical motifs also empower minoratarian cultures to respond to colonialism, and other forms of oppression.

The primary goal of this study has been to organize the theoretical study of universalism in a topical manner, in academic fields of human rights, cultures, and literary studies. In this sense, my treatment of universalism has been two fold. One, the identification of the ways absolutisms mimic universalism, and become oppressive to minority groups and cultures around the world. Two, the isolation of cross-cultural ethical motifs that allow minoratarian groups to challenge such oppressions through social movements and activism. In this study, the works of Hogan, Appiah, and Benhabib have been particularly effective in highlighting the differences between colonial ideologies and non-coercive minoratarian universalism, and revealing their thematic importance in Ghosh's novel. However, this method can also be effectively extended to other studies that have contributed to the recent revival of universalism. Indeed, the works of figures like Nussbaum, Sen, and Butler are especially noteworthy (though the list is not limited to them). Nussbaum's endorsement of cosmopolitan education over patriotism, as better suited to reflect on international human rights is a good example of this revivalist approach, and thus is ideally matched for such a study. ${ }^{35}$ Furthermore, this is also true of Sen, particularly, his endorsement of a non-coercive humanism in the treatment of society, politics and human rights in postcolonial India. ${ }^{36}$ Finally, this method can also allow valuable insights into Butler's defense of cultural universality, as it allows her to destabilize heteronormative constructions of gender and racial identities. ${ }^{37}$

In conclusion, we may return to our original reflections on posthumanism, connecting them now with the empathic universals developed in the novel and the theoretical accounts of Hogan, Appiah, Benhabib. Earlier, I distinguished two senses of humanism; one, arising from the historical movement of humanism in the West, and the consequent development of European colonialism. Two, arising out of certain open-ended presumptions that human cross-culturally share certain non-coercive emotive and ethical impulses, which have influence over their behaviors and actions. Thus, in adopting a posthumanist approach, this study simultaneously points out fundamental flaws in the historical practices of Western humanism, and other practices that relate humanism to coercive ends, and urges a revival of the term in more non-coercive and culturally inclusive terms. Clearly, Hogan, Appiah and Benhabib agree that ideologies based on absolutism, coercive cosmopolitan attitudes, and elitist universalisms are products of hegemonic perceptions of humanism, rooted in colonialism and related

\footnotetext{
See, for example, [1-12].

See, for example, [15].

See, for example, [16].

See, for example, [18].
} 
practices. However, these thinkers also identify a revival of humanism in the tentative presumption that certain ethical motifs shape social behaviors at a cross-cultural level, and in many cases also aid minoratarian responses to oppression. In this spirit, Hogan finds in universalism, the ethical motifs to shape minoratarian responses to oppression, broadly seen the thematic motifs and the individual stances of literary authors. In Appiah, cosmopolitanism expresses an open-ended humanism that functions to subvert coercive social perceptions, rooted in Eurocentrism and Afrocentrism. In Benhabib, a revival of humanism is rooted in the conception of 'cosmopolitanism without illusions,' an attitude that counters forces of elitist universalisms by relating principles of cosmopolitanism to social justices against oppression. Finally, in Ghosh's Sea of Poppies, motifs of shared humanity allow the possibility of individual and collective social resistance against colonial and indigenous forms of oppression. Through this study, I conceptualize a posthumanism that could more flexibly lead to a revival of humanism. I refrain from identifying "post-humanist" as a category to signify all things after human or humanism, implying an effort to rigidly overcome humanity or humanism. On the contrary, I urge an "unhyphenated" posthumanist awareness that certain cultural practices can and have historically attributed coercive meanings of humanism, and such absolutist ideologies are often countered by open-ended humanisms and ethical universalities.

Conflicts of Interest: The author declares no conflict of interest.

\section{References}

1. Derrida, Jacques, and Anne Dufourmantelle. Of Hospitality. Stanford: Stanford University Press, 2000.

2. Foucault, Michel. Madness and Civilization: A History of Insanity in the Age of Reason. New York: Vintage, 1988.

3. Fish, Stanley Eugene. Is There a Text in This Class?: The Authority of Interpretive Communities. Cambridge: Harvard University Press, 1980.

4. Bernstein, Richard J. Beyond Objectivism and Relativism: Science, Hermeneutics, and Praxis. Philadelphia: University of Pennsylvania Press, 2011.

5. Ashcroft, Bill, Gareth Griffiths, and Helen Tiffin. The Post-Colonial Studies Reader. London and New York: Taylor \& Francis, 2006.

6. Viswanathan, Gauri. Masks of Conquest: Literary Study and British Rule in India. New York: Columbia University Press, 2014.

7. Ahmad, Aijaz. In theory: Nations, Classes, Literatures. London: Verso, 2008.

8. Glenn, Evelyn Nakano. Unequal Freedom: How Race and Gender Shaped American Citizenship and Labor. Cambridge: Harvard University Press, 2009.

9. Young, Iris Marion. Justice and the Politics of Difference. Princeton: Princeton University Press, 2011.

10. Rorty, Richard. "Human Rights, Rationality, and Sentimentality." In The Philosophy of Human Rights. Edited by Patrick Hayden. St. Paul: Paragon House, 2001, pp. 241-57.

11. Putnam, Hilary, and James Conant. Realism with a Human Face. Cambridge: Harvard University Press, 1992.

12. Himmelfarb, Gertrude. The De-Moralization of Society: From Victorian Virtues to Modern Values. New York: Vintage Books/Random House. p. 19.

13. Hogan, Patrick Colm. Colonialism and Cultural Identity: Crises of Tradition in the Anglophone Literatures of India, Africa, and the Caribbean. Albany: SUNY Press, 2000.

14. Mangharam, Mukti Lakhi. "The universal is the entire collection of particulars': Grounding identity in a shared horizon of humanity." College Literature 40 (2013): 81-98. [CrossRef]

15. Nussbaum, Martha Craven, and Joshua Cohen. "Patriotism and Cosmopolitanism." In For Love of Country: Debating the Limits of Patriotism. Edited by Martha Nussbaum. Boston: Beacon, 1996, pp. 3-21.

16. Sen, Amartya. The Argumentative Indian: Writings on Indian History, Culture and Identity. New York: Farrar, Straus and Giroux, 2005.

17. Purakayastha, Bandana. "Contesting the Boundaries between Home and the World: Tagore and the Construction of Citizenship." In Rabindranath Tagore: Universality and Tradition. Edited by Patrick Hogan and Lalita Pandit. Madison: Farleigh Dickinson Press, 2003, pp. 49-64.

18. Butler, Judith, Ernesto Laclau, and Slavoj Žižek. Contingency, Hegemony, Universality: Contemporary Dialogues on the Left. London: Verso, 2000. 
19. Appiah, Kwame Anthony. Cosmopolitanism: Ethics in a World of Strangers (Issues of Our Time). New York: WW Norton \& Company, 2010.

20. Appiah, Anthony. "Cosmopolitan Patriots." In For the Love of Country? Edited by Martha Nussbaum. Boston: Beacon, 1992, pp. 21-29.

21. Baxi, Upendra. The Future of Human Rights. New Delhi: Oxford University Press, 2002.

22. Mutua, Makau W. "Savages, victims, and saviors: The metaphor of human rights." Harvard International Law Journal 42 (2001): 201-45.

23. An-Na'im, Abdullahi. "Islam and Human Rights." In Religion and Human Rights: An Introduction. Edited by John Witte, Jr. and M. Christian Green. New York: Oxford University Press, Inc., 2012, pp. 56-70.

24. Weissman, Deborah M. "The Human Rights Dilemma: Rethinking the Humanitarian Project." Columbia Human Rights Law Review 35 (2003): 259. [CrossRef]

25. Benhabib, Seyla. Dignity in Adversity: Human Rights in Troubled Times. New York: John Wiley \& Sons, 2013.

26. Michael Freeman. “The Philosophical Foundations of Human Rights.” Human Rights Quarterly 16 (1994): 491-514. [CrossRef]

27. Freeman, Michael. "The Problem of Secularism in Human Rights Theory." Human Rights Quarterly 26 (2004): 375-400. [CrossRef]

28. Osiatyński, Wiktor. Human Rights and Their Limits. Cambridge: Cambridge University Press, 2009.

29. Donnelly, Jack. "The relative universality of human rights." Human Rights Quarterly 29 (2007): 281-306. [CrossRef]

30. Nandy, Ashis. Intimate Enemy. Oxford: Oxford University Press, 1989.

31. Roy, Arnab Dutta. “Deconstructing Universalism: Tagore's Vision of Humanity.” South Asian Review 36 (2015): 177-94.

32. Ghosh, Amitav. Sea of Poppies. New York: Farrar, Straus and Giroux, 2008.

33. Mani, Lata. "Contentious traditions: The debate on sati in colonial India." Cultural Critique 7 (1987): 119-56. [CrossRef]

34. Spivak, Gayatri Chakravorty. Can the Subaltern Speak?. Basingstoke: Macmillan Education UK, 1988.

35. Bandyopadhyay, Sekhar. Caste, Culture and Hegemony: Social Dominance in Colonial Bengal. Thousand Oaks: Sage, 2004.

(C) 2016 by the author; licensee MDPI, Basel, Switzerland. This article is an open access article distributed under the terms and conditions of the Creative Commons Attribution (CC-BY) license (http://creativecommons.org/licenses/by/4.0/). 